\title{
When Europe Matters: The Impact of Political Information on Voting Behaviour in EU Referendums
}

\author{
SARA BINZER HOBOLT \\ Center for Political Studies, University of Michigan, USA
}

\begin{abstract}
This article investigates how voters decide in referendums on European integration. More specifically, it analyses how political information influences voting behaviour. It argues that political information conditions the way in which people make decisions in referendums. The impact of political information is examined not only at the individual, but also at the contextual level. It is hypothesized that variations in the context of the referendum - the intensity of the campaign - produce differences in the way in which citizens act in referendums. As the intensity of the referendum campaign increases, more information is available to citizens and voters will rely more heavily on sophisticated criteria, such as attitudes and issue positions on the European Union (EU). While the informational context influences voting patterns, individuals also vary in their awareness of politics. It is argued that people with high levels of political awareness receive more information and consequently rely more on their own attitudes and less on elite cues when deciding. These theoretical propositions are tested by analysing survey data from EU referendums in Denmark, Ireland and Norway.
\end{abstract}

Never overestimate the information of the electorate, but never underestimate its intelligence. ${ }^{1}$

\section{Introduction}

Direct democracy is becoming an increasingly common feature of the process of European integration. The first referendum on European integration took place in France in 1972, and since then 40 referendums on aspects of European integration have been conducted in member states and candidate countries. The scholarly debate on European referendums has focused on whether these referendums can be regarded as "second-order" elections where satisfaction with national governments determine voting behaviour, or whether voters decide on the basis of their attitudes towards European integration. In these studies, voters are generally treated as a

Correspondence Address: Sara Binzer Hobolt, National Election Studies, Center for Political Studies, 4131 ISR, 426 Thompson Street, Ann Arbor MI 48104, USA. Email: shobolt@isr.umich.edu 
uniform mass that respond in a similar fashion to elite cues, but differ in interests and preferences; and the exiting literature therefore tends to overlook the potential impact of differences in the political awareness of individuals. Moreover, since these explanations focus solely on the individual level, little or no attention is paid to modelling and measuring the impact of the campaign context. Yet variations in supply of and demand for political information are likely to influence the way in which people make political judgements by conditioning the impact of other deciding factors.

To explore these propositions, this article examines the impact of political information on patterns of voting behaviour in referendums on European integration. It is generally recognized that individual voters differ greatly in their ability and incentives to gather and understand political information and that this affects opinion formation processes (Downs, 1957; Zaller, 1991, 1992; Converse, 2000). Moreover, the opportunity for political learning also depends on the type of information available in the political environment. This paper thus examines variation in political information at two levels: individual and contextual. At the individual level, it is argued that voters' level of political awareness will act as a mediating factor that influences the relative importance of other factors determining voting behaviour. At the aggregate level, it is suggested that the campaign context interacts with individual level characteristics in influencing the vote, since intensive referendum campaigns provide a favourable informational environment that encourages citizens to absorb and process more information and consequently rely on more sophisticated decision criteria.

To begin with, this article presents a brief overview of the scholarly debate of voting behaviour in EU referendums. Thereafter, the impact of political information on opinion formation is discussed and a model is proposed of how campaign intensity and political awareness affect voting behaviour in EU referendums. The theoretical propositions are tested in an analysis of voting behaviour in referendums in Denmark, Ireland and Norway. By estimating a logit model with interaction terms, using data from post-referendum surveys, the relative importance of EU attitudes, partisanship and government satisfaction and the conditioning impact of information are evaluated. Finally, aggregate patterns of voting behaviour in different informational environments are compared to evaluate the possible impact of the campaign context.

\section{Theories of Voting Behaviour in EU Referendums}

The scholarly debate on voting behaviour in referendums on European integration has predominantly been a battle between three competing schools: the "attitude" school, the "second-order election" school and the "utilitarian expectations" school. The first school focuses on individuals' values and beliefs, and argues that voting behaviour in EU referendums reflects people's underlying broad attitudes towards European integration (Siune et al. 1994a, 1994b; Svensson 1994, 2002). An alternative explanation of voting behaviour in EU referendums is inspired by 
the "second-order" theory of elections. In "second-order elections", national issues tend to dominate the campaigns and voters are thus expected to use their vote as a means of signalling their satisfaction or dissatisfaction with the government or to follow the recommendations of national parties (Franklin, Marsh \& McLaren, 1994; Franklin, Marsh \& Wlezien, 1994; Franklin et al. 1995). In a recent study, Franklin (2002) has provided a synthesis of these two approaches, indicating that conditioning factors such as the salience of European matters may influence the extent to which second-order election factors are relevant. However, these propositions are not systematically conceptualized or empirically tested in this study. Finally, a third school contends that utilitarian expectations determine voting behaviour in EU referendums. Matthew Gabel (1998a, 1998b) has explained support for European integration as a function of individuals' ability to exploit the economic opportunities created by market liberalization in the EU. According to this rational economic actor model, individuals who believe they will benefit economically from European integration are more likely to vote "yes" in an EU referendum.

Whilst these approaches make informative predictions about voting behaviour in clusters of EU referendums, they fail to explain why the importance of various factors varies between referendums and across segments of the electorate. Why will voters sometimes follow elite cues, whilst at other times voting contrary to the recommendations of their parties? This article offers a model that examines the conditions under which these various explanations apply.

\section{Information Effects and Opinion Formation in EU Referendums}

Recent studies of opinion formation have emphasized the role of political information in making attitudes relevant for political behaviour. In his celebrated book on mass opinion, John Zaller (1992) has emphasized the role of political information in determining the effect of underlying attitudes:

The impact of people's value predispositions always depends on whether citizens possess the contextual information needed to translate their values into support for particular policies or candidates, and the possession of such information can ... never be taken for granted (Zaller, 1992: 25).

Studies in the field of political psychology have equally shown that information affects the attitude-behaviour relation, because attitudes tend to be consistent with behaviour to the extent that those attitudes are readily retrievable in behavioural situations (Krosnick, 1988; Lavine et al., 1996; Alvarez \& Brehm, 2002). Building on this research, two main "information effects" can be identified. First, information reduces attitude uncertainty, since additional information enables individuals to become increasingly certain in their opinions. Information on an issue can thus lead to stronger and more stable and accessible attitudes. Second, information makes predispositions and values relevant for beliefs about specific policy issues. In other 


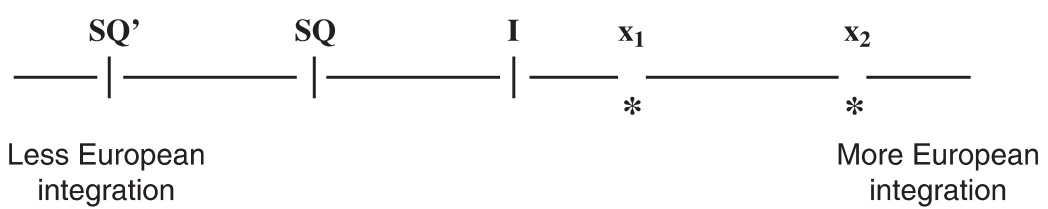

Figure 1. Simple spatial representation of the decision making in EU referendums

words, political information enables individuals to link attitudes with specific policies and in turn act on the basis of these attitudes. This is also relevant to the decision-making process in EU referendums, which can be illustrated with a simple spatial representation.

In Figure 1, the choice that voters face in a referendum on European integration is presented in a spatial model. In this example, the ballot issue may be the ratification of a Treaty or the adoption of a specific policy, and the continuum represents a range of policy options from Less European integration (for example, exit from the EU) to More European integration (for example, the creation of a United States of Europe). The voter's preferred option or "ideal point" $(I)$, the Status Quo $(S Q)$ and the ballot proposition $\left(x_{1}\right.$ or $\left.x_{2}\right)$ are located somewhere along this continuum. From the perspective of a voter with limited information, several uncertainties may exist. Assuming that the voter has an "ideal point" on this continuum (that is, specific attitudes towards the issue of more or less European integration), the voter may be uncertain about how this relates to the status quo and the specific ballot proposition. In order to make a competent and reasoned decision, voters must decide where the ballot measure and status quo are located and determine whether the proposition is closer to or farther away from their ideal point. They also need to assess whether a rejection of the proposal will lead to a continuation of the status quo ( $S Q$ ) or to an entirely new situation ( $S Q$ ') - for example an exit from the EU. If perfect information were available, the competent voter would vote in favour of a proposition located at $x_{1}$, but against a proposition located at $x_{2}$ (assuming the status quo is located at $S Q$ ). This attitude-behaviour relation is thus crucially determined by the amount of information available to the individual voter. When little information is available, voters may not know whether the ballot proposition is located at $x_{1}$ or $x_{2}$, or where the status quo stands or will remain (Bowler \& Donovan, 1998). Moreover, voters may not even have explicit preferences about European integration and they may choose to vote on the basis of a different issue altogether, such as domestic policy issues, or rely on elite recommendations.

The degree to which individuals are exposed to and process political information is thus likely to affect the importance of EU attitudes in referendums. This proposition is discussed in more detail below.

\section{The Political Environment as Informer and Motivator: Campaign Intensity}

Whereas studies of political information and political behaviour have tended to focus on individual heterogeneity in political awareness, political learning also 
depends on the salience of an issue in the public debate (Franklin \& Wlezien, 1997; Nicholson, 2003). In a recent study, Kuklinski et al. (2001) have shown how the political environment affects the quality of citizens' political decision making. Not only does the environment act as a source of information, it also plays a motivational role of encouraging citizens to invest effort and time in making political judgements. In referendums, voters form opinions in the context of the campaign environment, and it is therefore reasonable to assume that the intensity of the campaign can influence the criteria people employ when deciding on a ballot proposition. In contrast to election campaigns where parties provide relatively clear-cut information cues for voters, elite cues such as partisanship are less informative in referendums and the informational context of the referendums is thus likely to play a greater role (Le Duc, 2000).

The intensity of the campaign can be defined as "the level of information disbursement" leading up to a given election or referendum (Westlye, 1991: 17). To be more specific, it can be conceptualized as the interaction between the cues emitted by competing partisan and non-partisan actions, media coverage and the perceived closeness of the outcome (Kahn \& Kenney, 1997). The level of partisan polarization influences the nature and the intensity of competing elite cues by affecting campaign strategies and spending. The competitiveness of the contest is also likely to affect the intensity of the campaign, and in conjunction, these circumstances influence the way in which the news media decide to cover the referendum. The interplay of these factors contributes not only to the quantity of information available but also to the extent to which the environment encourage individuals to process information.

On the basis of this, it is suggested that when campaign salience is high, more information is available to individual voters and they are thus more motivated and better capable of making sophisticated judgements that are compatible with their underlying attitudes. Put differently, citizens will be more aware of the location of their "ideal point" on the European integration-continuum and better equipped to relate this to a specific ballot proposition (see Figure 1). In contrast, when campaign intensity is low, voters have limited access to easily available information and few incentives to make complicated decisions about the ballot proposal, and they are thus more likely to vote randomly or depend more heavily on cognitive short cuts. Hence, a high intensity campaign is generally likely to produce a better model fit, because voting behaviour is more predictable. Following this line of argument, the first hypothesis can be formulated: The higher the intensity of the campaign, the more voters will rely on their attitudes towards European integration when deciding in EU referendums.

While it is expected that the campaign environment will affect how voters make decisions, individuals also differ in their attention to political information and these differences are likely to influence patterns of voting behaviour at the individual level.

\section{Political Awareness and Voting Behaviour}

Variation in individual exposure to political information is often operationalized in terms of political awareness; that is, the extent to which an individual pays attention 
to and understands political information (Zaller, 1992: 21). Many studies of opinion formation have shown that people vary greatly in their attentiveness to political communication and that this variance influences the process of opinion formation (see, for example, Zaller, 1992; Converse, 1964, 2000; Alvarez \& Brehm, 2002). Yet, too little is still known about the behavioural consequences of this variation, as Converse has noted: "the degree of heterogeneity [of political information] is widely underestimated, and the implications of that dramatic heterogeneity seem even less well understood" (2000: 332). John Zaller's (1992) Receive-Accept-Sample (RAS) model is one of the few theoretical frameworks that emphasize the impact of political awareness. He argues that the processing of elite cues is highly dependent on an individual's level of political awareness. First of all, Zaller's reception axiom states that the greater a person's level of cognitive engagement with an issue, the more likely he is to be exposed to and comprehend political messages concerning the issue (Zaller, 1992: 58). In other words, the higher the level of political awareness, the more likely a person is to receive elite messages. However, the reception of elite cues does not necessarily imply that an individual will internalize and act in accordance with these messages. The second axiom in Zaller's model is the Resistance Axiom: people tend to resist arguments that are inconsistent with their political predispositions, but they do so only to the extent that they possess the contextual information necessary to perceive the relationship between the message and the predisposition (1992: 58). Thus, the level of political awareness influences the extent to which an individual can make the link between the elite cues and their underlying political attitudes.

In the context of EU referendums, this model can be used as a framework for understanding and predicting the impact of EU attitudes on voting behaviour. If we recall the competing explanations of voting behaviour discussed previously, the attitude school emphasizes the role of attitudes and values, whereas the second-order election school stresses the importance of elite cues, such as party endorsements and government satisfaction (Lupia \& McCubbins, 1998). Yet political awareness may act as an intervening variable determining the relative impact of these independent variables on the vote choice. In EU referendums, underlying attitudes towards European integration can be regarded as the most relevant political predispositions. Elite cues can be operationalized as the recommendations made by parties (partisanship) as well as the popularity and credibility of the information provider and agenda-setter (government satisfaction). Political awareness thus mediates the relative impact of EU attitudes and elite cues on voting behaviour. More aware people will be exposed to more political communication (via the reception axiom) but will be more selective in deciding which communications to internalize and only follow recommendations that are relatively consistent with their predispositions (via the resistance axiom). Hence, underlying attitudes are likely to be the strongest predictor of voting behaviour for this group of people. Following this line of reasoning, the second hypothesis can be formulated: People with high levels of political awareness will rely more on their attitudes towards European integration when deciding in EU referendums than people with lower levels of political awareness. 


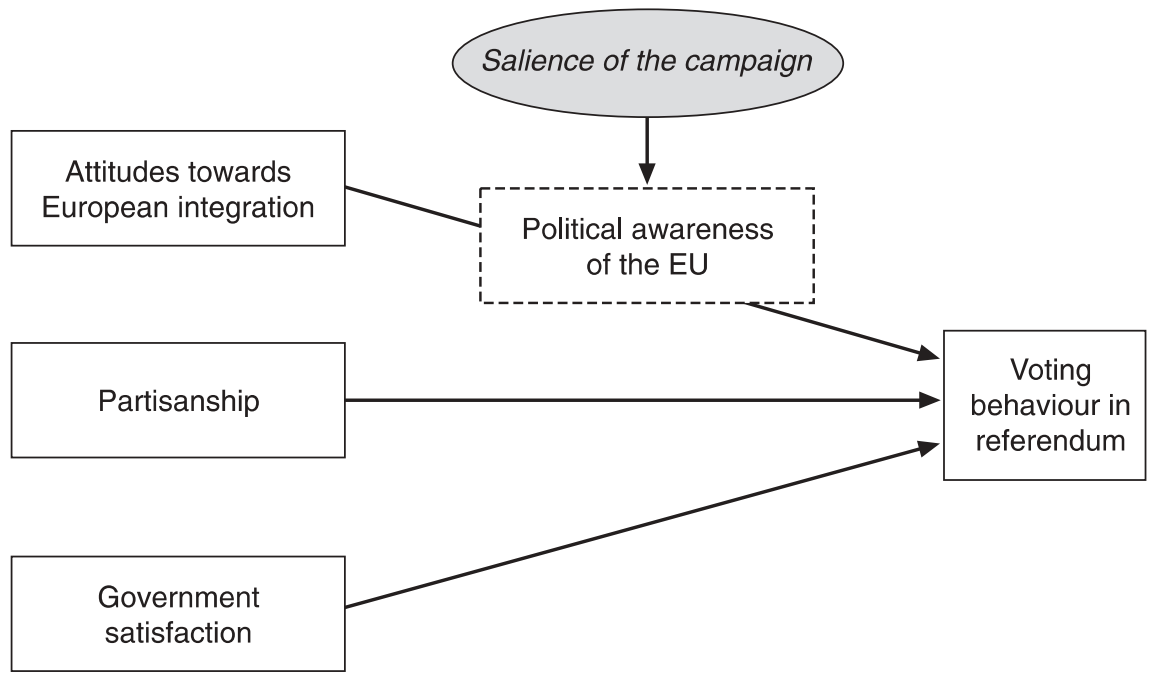

Figure 2. Model of voting behaviour in European referendums

By introducing political information as an intervening variable in the model, the intention is to arrive at a more sophisticated and accurate understanding of voter behaviour in referendums on European integration. The conditioning impact of political information at individual as well as the contextual level is illustrated in the theoretical model of voting behaviour in EU referendums presented in Figure 2.

\section{Modelling Voting Behaviour in Referendums}

This section evaluates the theoretical model of referendum behaviour using survey data from eight referendums (see Appendix). Referendums in Denmark, Norway and Ireland have been chosen, because these countries have held more than one referendum on aspects of the European integration process, ${ }^{2}$ and examining these cases thus allows one to compare cross-temporally as well as cross-nationally. Moreover, this set of cases provides large variation in both the dependent and independent variables, given that popular support and partisan polarization vary considerably between these countries. The campaign setting also differs substantially, as will be discussed in more detail below. In spite of the specific selection of cases, the aim is to present and evaluate a model of voting behaviour that is applicable to European integration referendums in general. Table 1 provides an overview of the cases analysed in this study.

The purpose of analysing these cases is firstly to examine the strength of the explanations put forward in the literature concerning attitude factors, second-order election factors and utilitarian expectation factors and thereafter to test the conditioning effect of political information. In the first model, EU attitudes, partisanship, government satisfaction and demographic variables (income, education, region, 
Table 1. List of cases

\begin{tabular}{lllcc}
\hline Year & Country & \multicolumn{1}{c}{ Ballot proposal } & Turnout (\%) & Result (\% Yes vote) \\
\hline 1972 & Norway & Membership of EEC & 79.2 & $46.5^{*}$ \\
1972 & Denmark & Membership of EEC & 90.4 & 63.3 \\
1992 & Denmark & Maastricht Treaty & 83.1 & $49.3^{*}$ \\
1993 & Denmark & Maastricht Treaty and & 85.5 & 56.8 \\
& & Edinburgh Agreement & & $47.8^{*}$ \\
1994 & Norway & Membership of EU & 89.0 & $46.9^{*}$ \\
2000 & Denmark & Joining the Euro & 87.8 & $46.1^{*}$ \\
2001 & Ireland & Nice Treaty ratification & 34.8 & 62.9 \\
2002 & Ireland & Nice Treaty ratification & 48.5 & \\
\hline
\end{tabular}

* proposal rejected

gender and age) are the main independent variables. In addition, political awareness has been included as an explanatory variable to assess whether it has a direct impact on voting behaviour. In the second model, the indirect impact of political awareness is assessed by including interaction terms with political awareness as the moderator variable.

The dependent variable in both models is yes/no vote in the referendum. Only respondents who actually voted are included in the analysis, since the aim is to explain and predict actual voting behaviour. ${ }^{3}$ The EU attitude variable is created by constructing an attitude scale based on the summated rating (or "Likert") model. The method of summated rating assumes that people respond to separate specific EU attitude and policy questions on the basis of their underlying attitudes towards European integration. This method assumes that the items display monotone homogeneity; that is, they reflect a single underlying trait (DeVellis, 1991; Jacoby, 2000: 764). In the context of European attitudes, it seems valid to assume that individuals may have underlying attitudes towards the EU that guide their responses to specific questions on the EU (that is, more or less European integration). Moreover, several tests ${ }^{4}$ have been carried out to ensure that the assumption of one-dimensionality holds. One of the advantages of using the summated scaling technique is that a more precise and accurate interval-level estimate of the attitude dimension is achieved than can be obtained from any single item (DeVellis, 1991). Reliability analyses and inter-item analyses confirm that the attitude scales are highly reliable and internally consistent (Cronbach's alpha is more than .80 for all of the attitude scales).

The political awareness scale has also been constructed using the summated scaling technique. Zaller has evaluated the advantages of different measures of political awareness on the basis of attitude stability, consistency and the attitude-behaviour relation, and has found that neutral factual information is on both theoretical and empirical grounds the preferred measure (Zaller, 1992: Appendix; Converse, 2000). Hence in this study, the political awareness scale ${ }^{5}$ has been measured using items of neutral political knowledge, supplemented by measures of subjective political 
knowledge, political interest and media exposure, ${ }^{6}$ but measures of education have not been included in this scale. ${ }^{7}$ The awareness scales all have alpha reliabilities in the .80 to .90 range, and thus have high internal consistency. Partisan cues are measured by recoding the question on party support ${ }^{8}$ into a five-point scale of the different parties' European stance and recommendations. By creating a scale, rather than an dichotomous yes/no party variable, this allows a differentiation between parties that are united in the support of (or opposition to) the referendum and parties that are split on the issue and consequently send mixed cues to their supporters. ${ }^{9}$ In addition, the impact of the strength of partisan identification is assessed by including a five-point scale of party identification (where data are available). Government satisfaction is measured as a Likert scale relating to how satisfied the respondent is with the government's performance.

In addition to these variables relating to attitudes and elite cues, the model also includes variables relating to Gabel's utilitarian expectation explanation (Gabel, 1998a; 1998b). By including five-point scales of income and education levels, the model is testing whether or not the "human capital hypothesis" is significant in terms of influencing voting behaviour in EU referendums. The expectation of the human capital hypothesis is that respondents who are not obtaining educational or occupational skills will form less favourable utilitarian evaluations of integration than groups with better occupational skills and higher levels of education. Demographic controls of age, gender and region (urban versus rural scale) are also included as variables in the model. This full model is tested using logistic regression, because of the dichotomous nature of the dependent variable. Table 2 shows the results when evaluating this model using survey data from eight national EU referendums held in Denmark, Ireland and Norway during the past three decades. ${ }^{10}$

The results in Table 2 clearly indicate that EU attitudes and partisanship are the most important factors determining voting behaviour in EU referendums. The less people are in favour of steps towards further integration (high attitude score), the more likely they are to vote against the ballot proposal. Equally, individuals who support parties recommending a "No" vote are more likely to vote against the proposal. These variables are significant in each of the eight referendums evaluated. In addition, government satisfaction also seems to influence voters' decisions in some of the referendums. Perhaps surprisingly, political awareness does not seem to have a substantial direct impact on how people vote. This supports the suggestion that the impact of political awareness is primarily indirect (conditioning other factors), rather than direct." The impact of "human capital" factors, such as education and income are insignificant when controlling for attitudes and partisanship. Hence, whilst the utilitarian approach may be useful in explaining the origins of EU attitudes, it is less valuable in the context of voting behaviour in EU referendums. Equally, the other demographic variables - region, gender and age - are all insignificant. ${ }^{12}$

In order to test the hypotheses regarding the impact of political awareness, an alternative model needs to be specified. As the primary interest is in the indirect effect of political awareness, the second model examines how political awareness affects the relative importance of other factors determining voting behaviour.The 


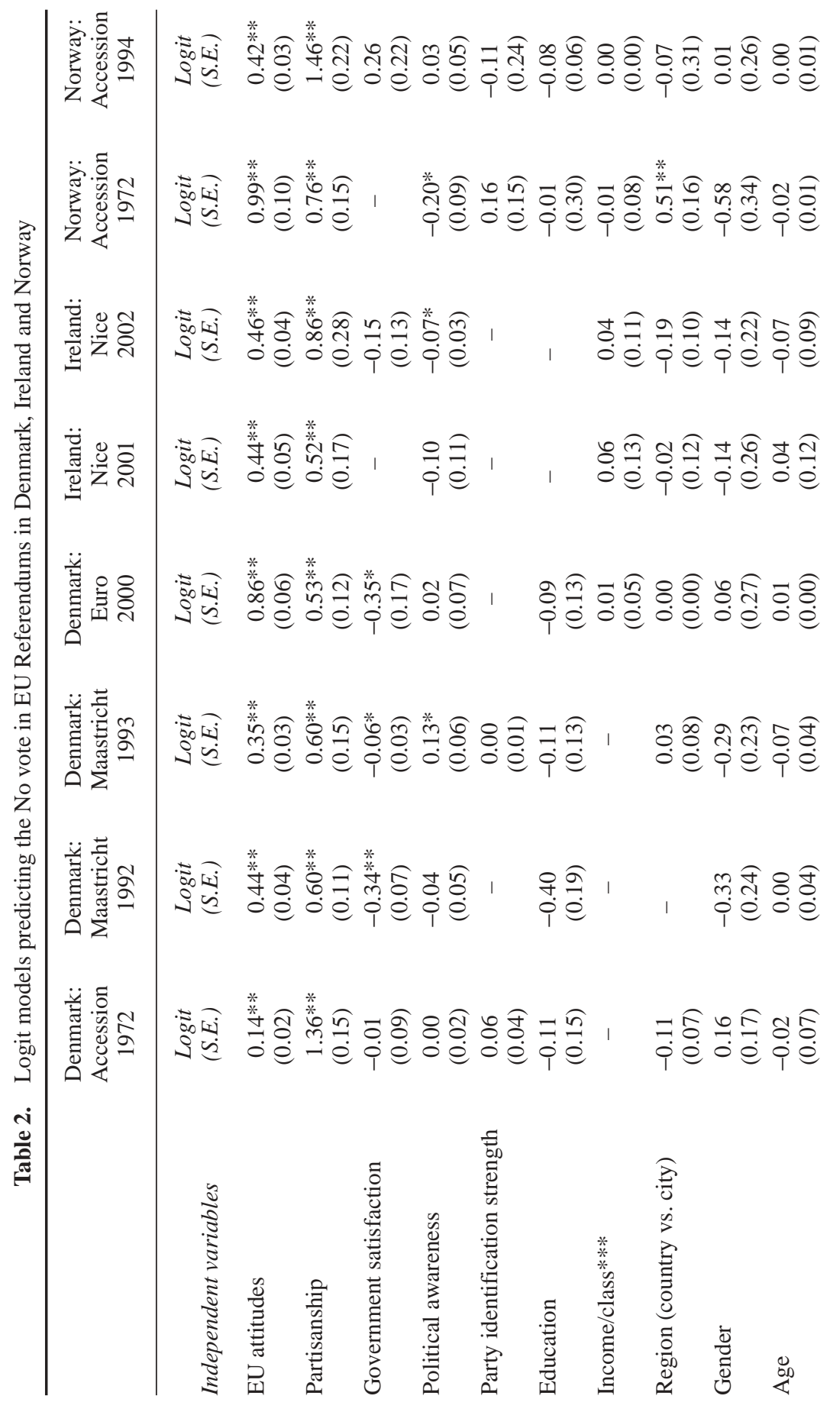




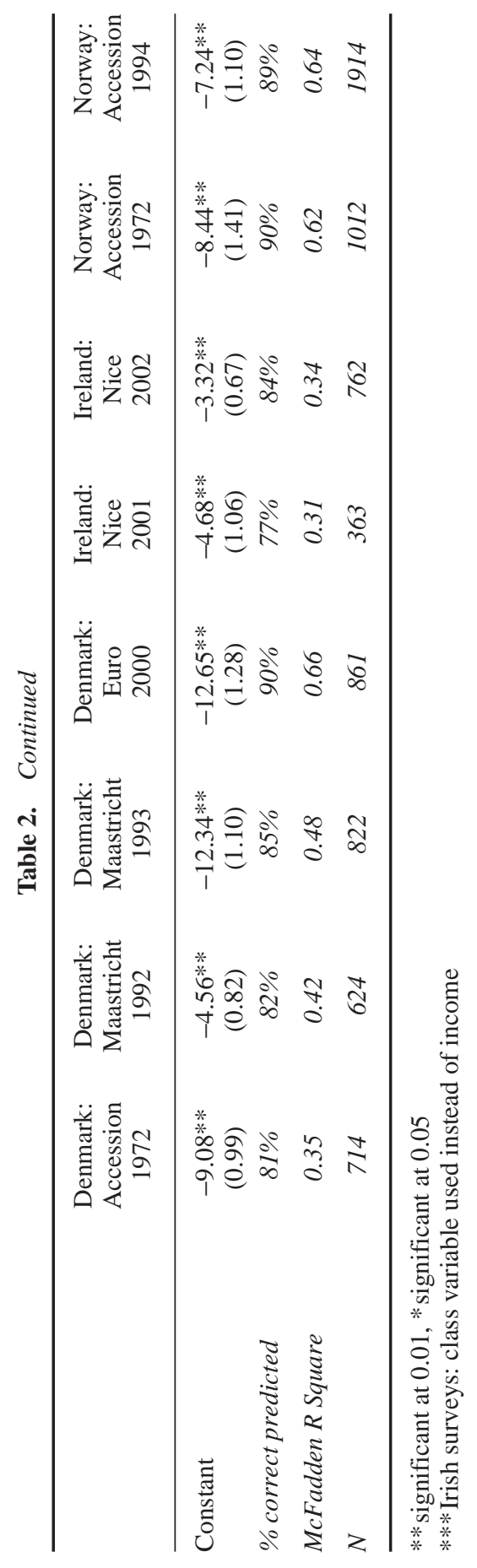


conditioning impact of one variable on the effect of the other independent variables can be evaluated by including an interaction term in the model (Jaccard, 2001). Thus by using multiplicative interaction terms to specify the interaction between different levels of political awareness and the independent variables, one can assess whether the effect of the explanatory variables (attitudes and elite cues) depends on political awareness. To begin with, a simplified version model is therefore evaluated - only including the significant independent variables of EU attitudes, partisanship and government satisfaction - and adding multiplicative interaction terms, $\mathrm{X}_{1} \mathrm{X}_{2}$, where $X_{1}$ represents each of the explanatory variables. Since the main interest is in comparing the decision criteria of the group of voters with high levels of political awareness with groups of voters with medium and low levels of political awareness, the political awareness scale has been transformed into a trichotomous (low, medium, high) political awareness variable, ${ }^{13}$ and $\mathrm{X}_{2}$ therefore denotes two dummy variables of high- and medium-level political awareness. The results are shown in Table 3.

The coefficients for the attitude variables and their interaction with high political awareness are statistically significant (at .05 level) in all but one referendum (the first Irish referendum on the Nice Treaty), whilst the direct impact of attitudes remains significant in all referendums. Moreover, the coefficients for the interaction between medium political awareness and EU attitudes are statistically significant in six of the eight referendums. This indicates that people with higher levels of political awareness rely more heavily on their EU attitudes when deciding in referendums than people with low levels of political awareness. This supports the second hypothesis relating to the impact of differences in political awareness. The interaction between political awareness and the remaining independent variables, partisanship and government satisfaction, is not statistically significant. Moreover, a likelihood ratio test of the model with and without interaction terms shows that the fit improves when the interaction terms are included.

However, while it is relatively straightforward to estimate and interpret interaction effects in linear models, this is not the case in logit models, and there is no consensus in the field about the most appropriate way to do this (Berry \& Berry, 1991; Berry, 1999; Nagler, 1994; Norton et al., 2004). There are several difficulties with interpreting the marginal effects and signs of interaction term coefficients in the same way as one would do in linear models, and the familiar odds-ratio interpretation cannot be applied (Ai \& Norton, 2003; Norton et al., 2004). Furthermore, it has been argued that since logit models are inherently interactive with respect to the effects of the independent variables $\left(\mathrm{X}_{1}, \mathrm{X}_{2}\right)$ on the probability of the dependent variable $(\operatorname{Pr}(\mathrm{Y}=1))$, it may not even be necessary to include interaction terms in order to detect interaction. In fact Berry (1999) argues that in cases where the dependent variable of interest is whether some discrete event occurs (rather than the underlying unbounded concept $\mathrm{Z}$ presumed to be measured by $\mathrm{Y}$ ) - such as whether individuals vote "yes" or "no" in an EU referendum - one cannot perform a statistical test of the hypothesis that $\mathrm{X}_{1}$ and $\mathrm{X}_{2}$ interact in influencing $\operatorname{Pr}(\mathrm{Y}=1)$ against the null hypothesis that there is no interaction, because there can be no logit or probit 


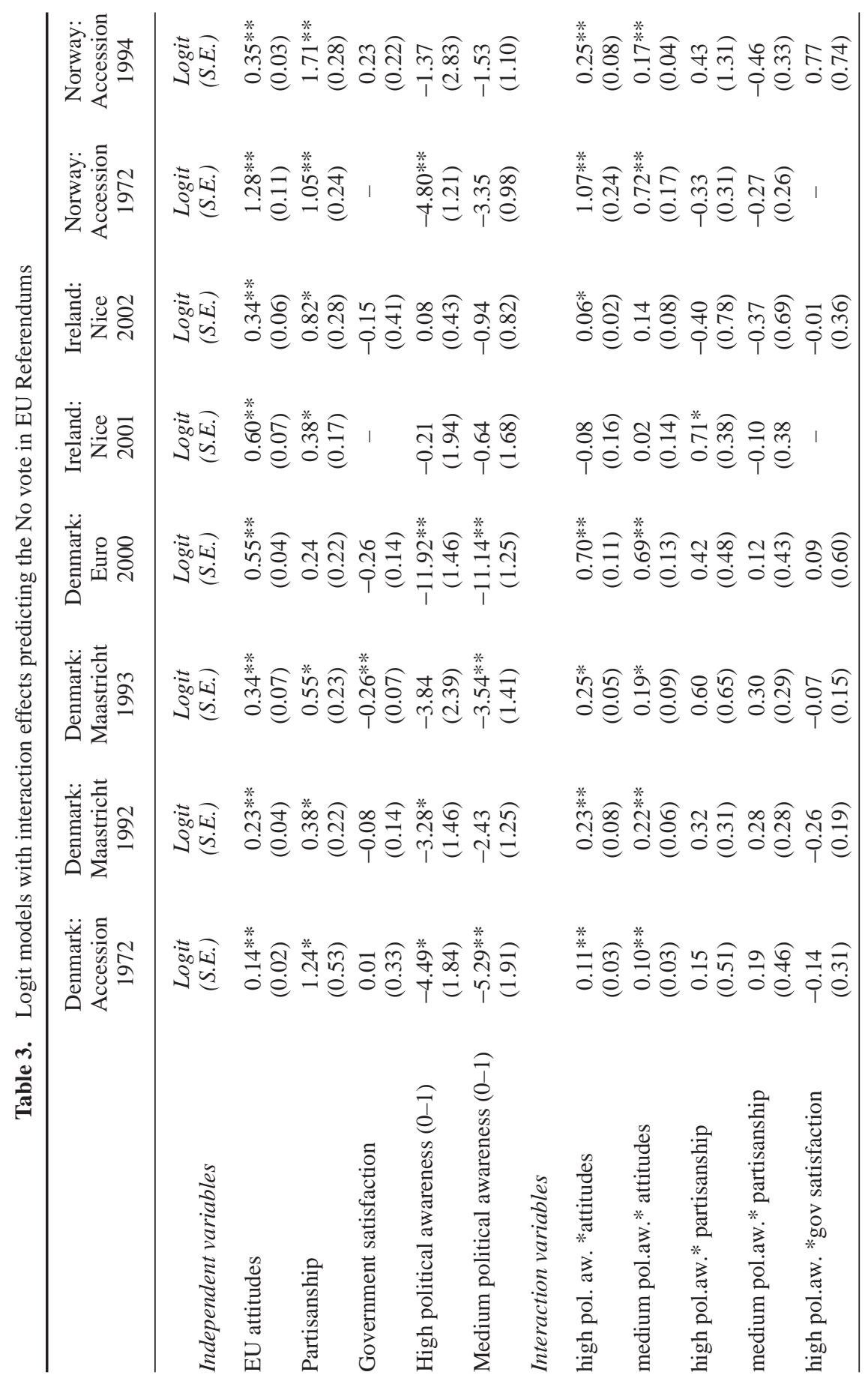




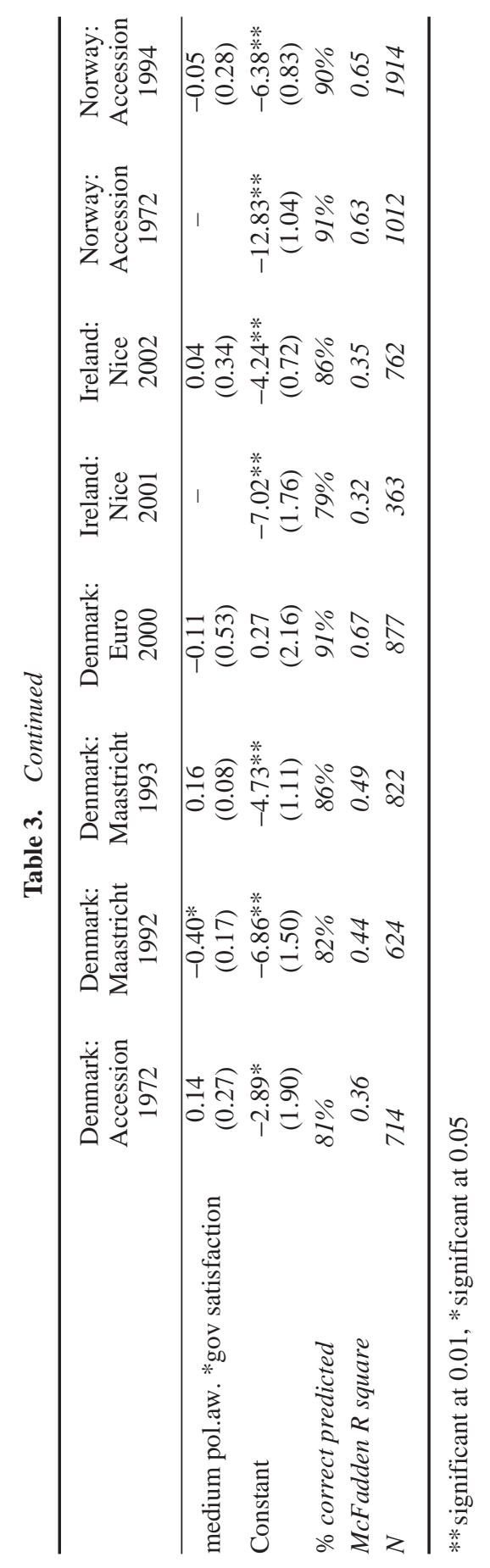


model in which the effect of $\mathrm{X}_{1}$ on $\operatorname{Pr}(\mathrm{Y}=1)$ is completely independent of the value of $\mathrm{X}_{2}$. Instead Berry (1999) recommends comparing the changes in predicted probabilities, $\operatorname{Pr}(\mathrm{Y}=1)$, across different levels of $\mathrm{X}_{2}$, using maximum likelihood estimation, to see if the differences are as predicted by the hypotheses.

Following this line of reasoning, the proposed hypothesis is evaluated by comparing the predicted probabilities, $\operatorname{Pr}\left(\mathrm{Y}=1\right.$ ), when $\mathrm{X}_{1}$ (either attitudes, partisanship, or government satisfaction) is increased by a specified amount across three levels of $\mathrm{X}_{2}$ (political awareness). In other words, by stratifying the electorate into three levels of political awareness (low, medium, high) and testing the simplified model for each level, a comparison can then be made between the relative impact of the different explanatory variables. This technique gives one a better indication of the substantive effects of the independent variables. This article uses simulation techniques ${ }^{14}$ to demonstrate how the referendum vote would change as the value of each independent variable changes ceteris paribus. Each selected variable has been changed by half a standard deviation (keeping all other variables at their mean) to ensure comparability across samples. The results for each strata of the sample of voters in each post-referendum survey are reported in Tables 4 (Danish referendums) and 5 (Irish and Norwegian referendums), including the $95 \%$ confidence interval for each prediction.

As indicated by the significant interaction terms in Table 3, the results in Tables 4 and 5 show that the impact of EU attitudes are greater, the higher the level of political awareness. In every single referendum, the impact of a change in the EU attitude variable is greatest for the "high political awareness" group of voters.

Moreover, the results presented in Tables 4 and 5 allow us to compare the impact of different factors across the eight referendums. In the previous section, it was hypothesized that the salience of the campaign would influence the patterns of voting behaviour in EU referendums. The most appropriate method of assessing whether the relationship between variables measured at the individual level depends on variables measured at the aggregate level is to use multi-level modelling; yet, unfortunately such a model cannot be safely estimated with only eight "level two" cases (Stoker \& Bowers, 2002). But even without a statistical significance test of the campaign effect, these cases may still provide some suggestive evidence of whether this hypothesis holds. Hence, in order to evaluate the first hypothesis concerning the impact of the campaign context, a comparison can be made between the relative patterns of voting behaviour (shown in Tables 4 and 5) with the intensity of the campaign environment in each of the eight referendums.

\section{Campaign Intensity}

As discussed above, the intensity of the referendum campaign can be operationalized as the interplay of the following indicators: partisan polarization, campaign activity of partisan and non-partisan actors, media coverage and the perceived closeness of the race. To establish that this is a reliable and valid measure that can be applied cross-nationally and cross-temporally, it is necessary to describe the individual indicators in some more detail. 


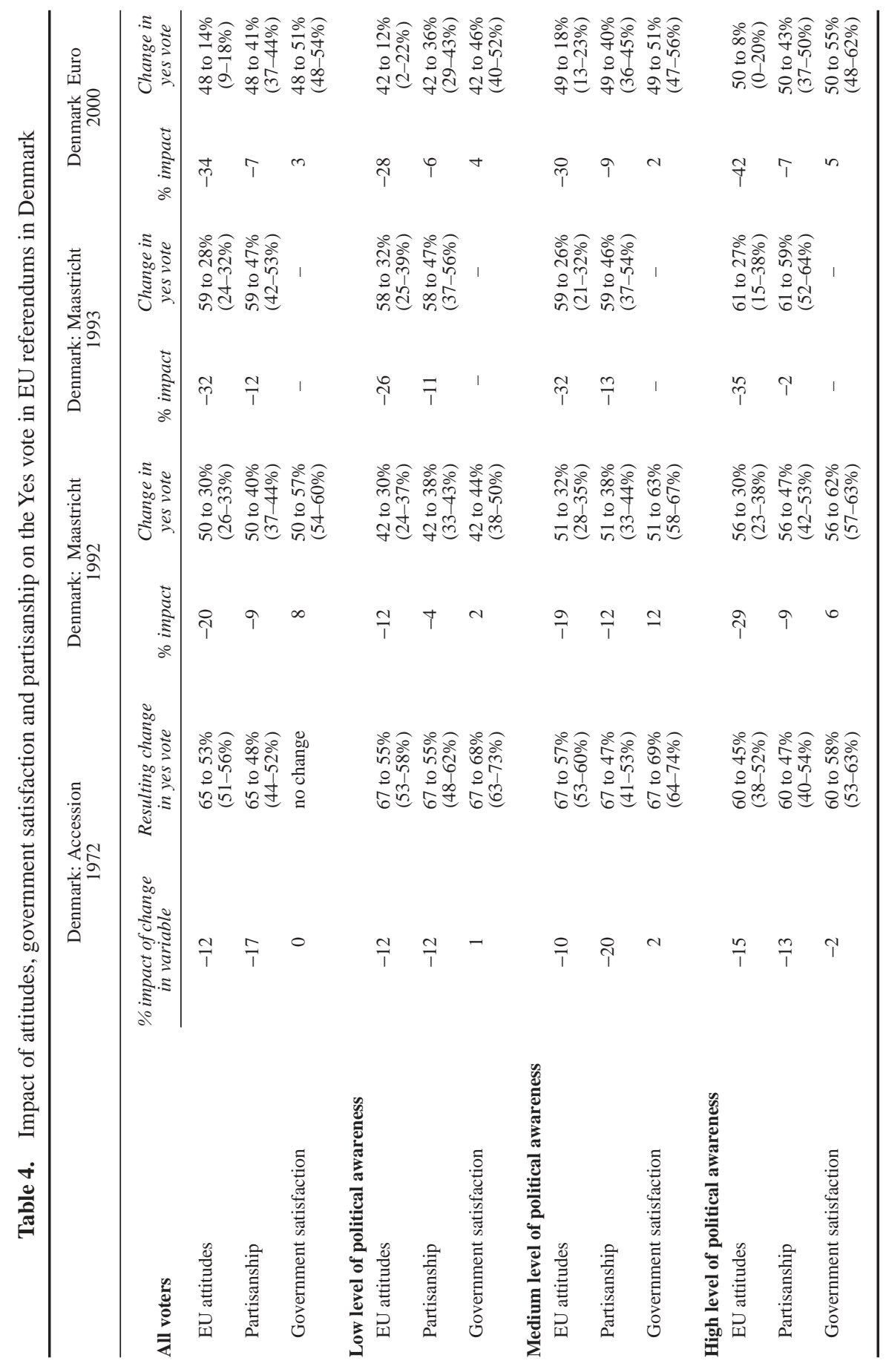




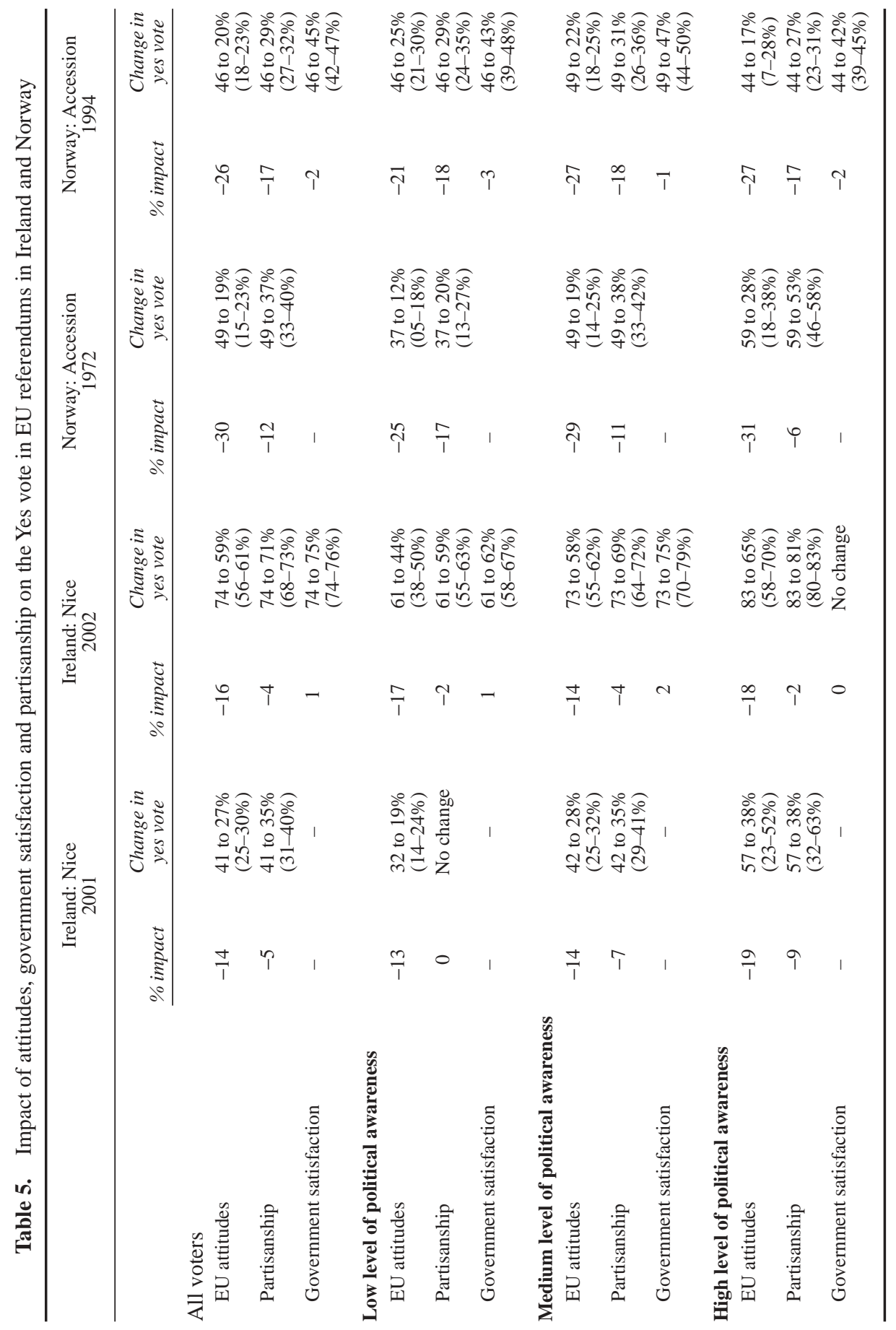


Partisan polarization on the ballot proposition is the first indicator of the salience of the campaign, since competing partisan views are likely to lead to increased intensity of the campaign environment. In a situation where there is no partisan opposition to the ballot proposal, the referendum is also likely to be less salient to news media and voters. Partisan polarization is measured as the percentage of parties (as a proportion of their share of parliamentary seats) who recommend a "No" vote in the referendum. ${ }^{15}$ The perceived public stance on the issue is also likely to influence the campaign environment. If the public is perceived to be equally divided on the issue, the salience of the issue is likely to be higher than if there is thought to be a large majority in favour of the proposal. The perceived closeness of the race is measured by evaluating the opinion polls in the month leading up to the vote, and measuring the margin between yes and no-voters, as well as numbers of undecided voters. Both partisan polarization and the perceived closeness of the race are likely to influence the third indicator: campaign spending. The total amount of money ${ }^{16}$ spent by partisan and non-partisan actors during the campaign can be considered a proxy of campaign activity (Kahn \& Kenney, 1997: 1183). The higher the salience of the campaign, the more likely actors are to spend considerable campaign funds. Unfortunately, the measurement of this indicator is problematic, because some organizations are unwilling to disclose the exact spending figures, and it has therefore been necessary to rely on estimates provided by the news media and experts, in addition to official documents.

Finally, news coverage of the referendum issue is a good indicator of the information available to the citizens Voter awareness of a ballot proposition is likely to grow with increasing media coverage and can also be seen as a general indicator of the salience of the campaign. Numerous political communication studies provide ample evidence that there is a strong relationship between the quantity of media coverage afforded to an issue and the publicly perceived salience of this issue (see, for example, Shaw \& Martin, 1992; Dearing \& Rogers, 1996). In this study, news coverage has been analysed by measuring the average number of daily articles mentioning the referendum issue in the three months leading up to the referendum in two mainstream daily national newspapers with a high circulation. ${ }^{17}$ While not all voters will read the largest circulating newspapers, the news media will tend to respond in a similar fashion to the standard criteria of "newsworthiness" (Kahn \& Kenney, 1997: 1883). Hence, the referendum coverage in two large daily newspapers is a good indicator of the general level of media coverage of the campaign. Employing these indicators (all measured using five-point scales), the overall intensity of the referendum campaigns examined in this study is shown in Table 6.

Table 6 shows that the campaign environment was most intense in the 2000 Danish referendum on accession to the common European currency, followed by the two Norwegian referendums on membership of the EU (1972 and 1994). Curiously, these three referendums all ended with a popular rejection of the ballot proposal. This may be related to the proposition that elite cues are both more divided and less persuasive in a high salience environment. The campaigns leading up to the two Danish referendums on the ratification of the Maastricht Treaty (the first was 


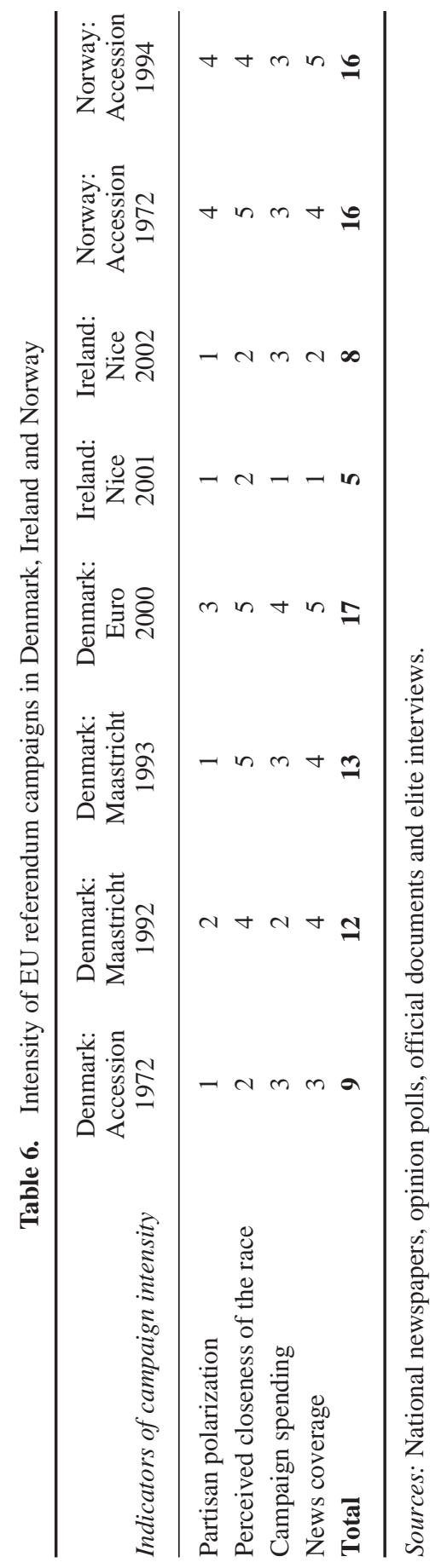


rejected by the voters) were also highly salient, whereas the campaigns on the Irish Nice Treaty and the Danish accession to the European Economic Community (EEC) in 1972 were less intense.

According to this article's first hypothesis, a high salience campaign environment will encourage voters to rely more on their attitudes toward the ballot proposition when deciding. In order to be easily able to compare the impact of attitudes in different referendums with the campaign intensity, Figure 3 provides a overview of the predicted impact of a change in the attitude variable in the eight referendums, stratified by level of political awareness (using the predicted probabilities shown in Tables 4 and 5).

Figure 3 shows that the impact of attitudes was greatest in the referendums with the most intense campaigns: the Danish Euro referendum, the Norwegian referendums and the second Maastricht referendum. The correlation between campaign intensity and the percentage impact of half a standard deviation change in the attitude variable is 0.87 . These findings therefore corroborate the proposition that as campaigns become more intense, citizens will be more likely to draw connections between their own ideological and issue positions and the ballot proposal. The hypothesis of this article is that when the intensity of campaigns is high, voters will have access to more information and be more motivated to process information and consider the implications of their decisions. This implies that voters are less likely to vote randomly, and consequently that the proposed model of voting behaviour has greater explanatory power. If a comparison is made between the measures of model fit across the referendums, it is found that the referendums that provide the best fit (the Danish Euro referendum and the two Norwegian membership referendums) are

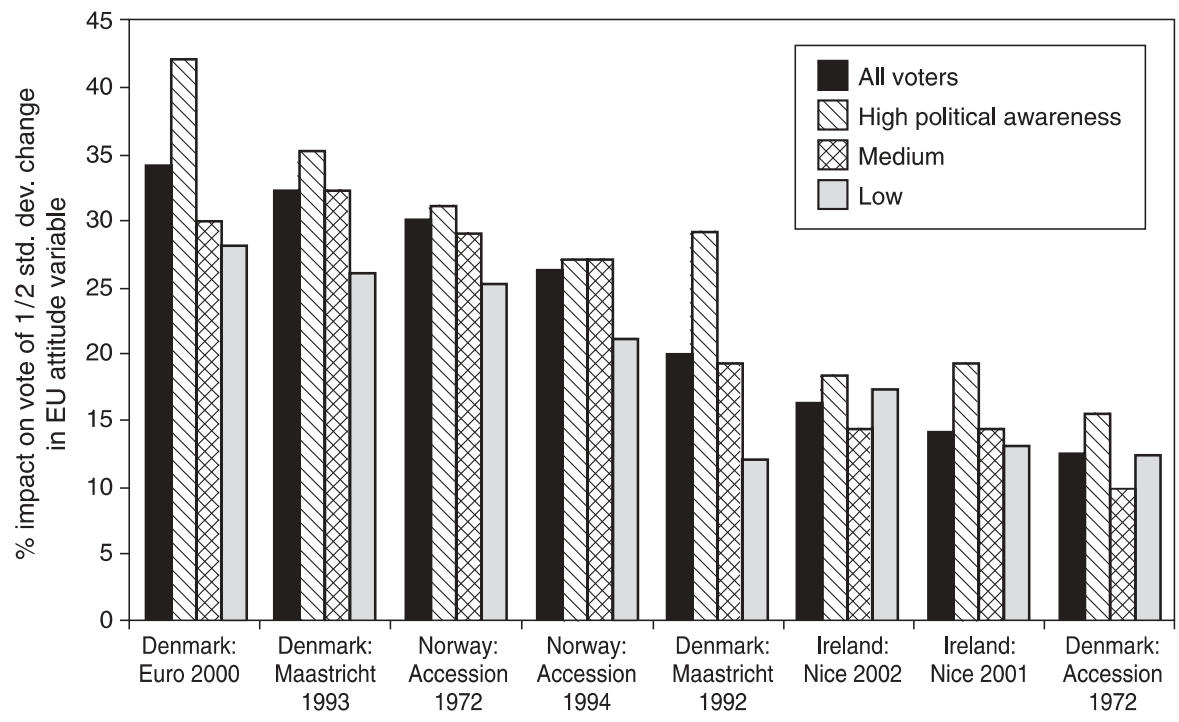

Figure 3. Overview of the impact of change in EU attitude variable on the vote 
also the referendums with the most intense campaign context. The $\mathrm{N}$ is too small to make any firm conclusions on the basis of this evidence, but it does suggest that high campaign intensity may increase the general predictability of voting behaviour, because citizens are able and motivated to make reasoned decisions based on their attitudes. In contrast, in a low-salience campaign where information about the ballot issue is scarce, individuals have little incentive to make complicated judgements about the issue of European integration.

\section{Conclusion}

As Zaller has noted,

most of the time, when scholars attempt to explain public opinion and voting behaviour, they build models that implicitly assume all citizens to be adequately and about equally informed about politics, and hence to differ mainly in their preferences and interests. In other words, they build models that ignore the effects of political awareness (1992: 18).

This paper has made an attempt to provide a corrective for this practice in the field of European referendum studies by assessing how political information influences the relative impact of political predisposition and partisanship on vote choice in EU referendums. The analyses of voting behaviour in eight Danish, Irish and Norwegian referendums give fairly conclusive results: people with high levels of political awareness rely more on their EU attitudes when voting in European referendums. These findings are promising, because they give us a better understanding of the patterns of voting behaviour in referendums. They also allow us to draw some, at least tentative, theoretical conclusions that are broadly applicable to European referendums. The application of the model of voting behaviour to these eight cases has demonstrated that both elite cues and underlying attitudes play a significant role in determining voting behaviour, but that the relative impact of these factors is partly determined by the individual voter's awareness of politics in general.

Moreover, this article has found that the campaign context interacts with individual level decision-making criteria in influencing the vote. When the intensity of the campaign is high, voters are more likely to make reasoned and competent decisions and vote on the basis of their attitudes on European integration. With only eight cases, it has not been possible to provide a conclusive statistical evaluation of this theoretical proposition. Yet the preliminary findings presented here strongly support the hypothesis, and thus provide a promising starting point for further research into the impact of the campaign context on patterns of voting behaviour in European referendums. 


\section{Appendix: Data Sources}

The analyses presented in this paper are based on data from the surveys referenced below. The author is grateful to Jens Wagner and the Danish Data Archive for making the Danish surveys together with the relevant documentation available and to the Norwegian Social Science Data Service (NSD) for giving her access to the Norwegian referendum surveys. The Irish Nice public opinion surveys conducted after the two Nice referendums were kindly provided by the Commission Representation in Ireland and EOS Gallup. The responsibility for the analyses and interpretations presented in this paper rests solely with the author.

\section{Surveys}

EF-undersøgelsen 1972 (før-efter), Primary Investigators: Jørgen Elklit, Peter Hansen, Nikolaj Petersen and Ole Tonsgaard. DDA-194, Second Edition by Claus Lewinsky and Karsten Boye Rasmussen. Odense, Danish Data Archive, 1982.

Observa prøvevalg 1972, Primary Investigator: Observa, DDA-0909, First Edition by Henning Lauritsen, Jens Wagner, Kirsten Pagh and Karsten Boye Rasmussen, Odense, Danish Data Archive, 1994.

Folkeafstemningen om Maastrichtaftalen, 1992, Primary Investigators: Karen Siune, Ole Tonsgaard, Palle Svensson. DDA-1743, First Edition by Brigitte Jensen and Søren Hviid Pedersen, Odense, Danish Data Archive, 1999.

Folkeafstemningen om Edinbrughaftalen, 18. maj 1993, Primary Investigators: Karen Siune, Ole Tonsgaard, Palle Svensson. DDA-1783, First Edition by Jette Strand og Birgitte G. Jensen, Odense, Danish Data Archive, 2000.

Euro-afstemningen 2000, DDA-4013, First Edition, Odense, Danish Data Archive, 2003.

Treaty of Nice Referendum 2001, Public Opinion Survey carried out for the European Commission Representation in Ireland by Irish Marketing Surveys Limited, in association with EOS Gallup Europe. Primary Investigator: Richard Sinnott.

Treaty of Nice Referendum 2002, Public Opinion Survey carried out for the European Commission Representation in Ireland by Irish Marketing Surveys Limited, in association with EOS Gallup Europe. Primary Investigator: Richard Sinnott.

Folkeavstemningen om EF - 1972, Survey data were made available by the Norwegian Social Science Data Service (NSD). The dataset is owned by Statistisk Sentralbyrå Seksjon for intervjuundersøkelser (SSB).

EU-avstemningen 1994, Survey data were made available by the Norwegian Social Science Data Service (NSD). The dataset is owned by Statistisk Sentralbyrå Seksjon for intervjuunders $ø$ kelser (SSB). 


\section{Notes}

1. Philip Converse quoting Mark Shields, a political columnist, referring to the American electorate (Converse, 2000: 331).

2. Ireland and Denmark have each held six European integration referendums, whereas Norway has held two accession referendums. Unfortunately, survey data are not available from all of the Irish referendums. Sweden has also held two EU referendums - on accession (1994) and joining the euro (2003) - but survey data on the 2003 referendum are not yet available. Moreover, Switzerland has held several referendums on Swiss relations with the EU.

3. A separate model with turnout as the dependent variable (including all respondents) has also been evaluated. The results of evaluating this model showed that political awareness has a considerable and significant impact on whether or not an individual votes in EU referendums.

4. The attitude items have been analysed using multidimensional scaling, Mokken scaling and principal component analysis techniques.

5. A "European political awareness" scale was also created, based on items solely related to objective knowledge of and subjective interest in European political matters. Yet since this scale had an almost perfect correlation with the more general "political awareness" scale in the cases under investigation, it was decided to use the "political awareness" scale.

6. Examples of question items included in the political awareness scale are: "How many members are there in Parliament?" (neutral information), "How knowledgeable are you about the EU?" (subjective knowledge) "Would you say that you are very interested in politics?" (political interest question), "Do you read a daily newspaper?" (media exposure).

7. It is common to use education as a proxy of political awareness; yet in this study it was found that education does not adequately capture the theoretical construct of political awareness, and the correlation between the education variable and the political awareness variable (objective and subjective political awareness) is not sufficiently high to justify using a measure of education alone.

8. "Which party will you vote for in the next General Election?"

9. This party scale has been created on the basis of party documents as well as information gathered in elite interviews with politicians. A score of five points were given to parties united against the referendum proposal and one point was given to parties united in favour, whereas yes-parties with a significant group of dissenters were given two points, and neutral parties were given three points.

10. It has unfortunately not been possible to test for the effect of all of the independent variables in each of these referendums, since not all of the post-referendum surveys included the necessary questions.

11. Only in the second Irish Nice referendum and in the 1972 Norwegian accession referendum did high levels of political awareness make it more likely for people to vote "Yes". In the second Danish referendum on the Maastricht Treaty, high levels of political awareness seem to have had the opposite effect.

12. With the notable exception of the first Norwegian referendum on EEC membership, where voters in rural districts were far more likely to vote against accession.

13. Using the political awareness scale rather than the dummies produces very similar results.

14. These simulations were carried out using the CLARIFY 2.1 software developed by Tomz et al. (2003).

15. If the parties recommending a "No" vote have less than $10 \%$ of the seats in parliament (or if no parties recommend a "No" vote), the polarization score will be one, less than $20 \%$ it will be two, and so forth. If the parliamentary parties are equally divided on the issue, the score will be five.

16. In coding campaign spending, it has also been estimated as a proportion of gross domestic product (GDP) at the time of the referendum, to be able to compare cross-nationally and crosstemporally. 
17. The Danish newspapers analysed were Berlingske Tidende and Politiken; the Irish newspapers were the Irish Independent and the Irish Times; and the Norwegian newspapers analysed were Aftenposten and Dagbladet.

\section{References}

Ai, C. \& Norton, E.C. (2003) Interaction terms in logit and probit models, Economics Letters, 80(1), pp. 123-129.

Alvarez, R.M. \& Brehm, J. (2002) Hard Choices, Easy Answers (Princeton, NJ: Princeton University Press).

Berry, F.S. \& Berry, W.D. (1991) Specifying a model state policy innovation, American Political Science Review, 85(2), pp. 573-579.

Berry, W.D. (1999) Testing for interaction in models with binary dependent variables. Unpublishe manuscript, Department of Political Science, Florida State University.

Bowler, S. \& Donovan, T. (1998) Demanding Choices: Opinion, Voting, and Direct Democracy. Ann Arbor, MI: The University of Michigan Press.

Converse, P.E. (1964) The nature of belief systems in mass publics, in: D. Apter (Ed.) Ideology and discontent (New York: Free Press).

Converse, P.E. (2000) Assessing the Capacity of Mass Electorates, Annual Review of Political Science, 3, pp. 331-353.

Dearing, J. W. \& Rogers, E. (1996) Agenda Setting (Thousands Oaks, CA: Sage).

DeVellis, R.F. (1991) Scale Development. Theory and Applications (London: Sage).

Downs, A. (1957) An Economic Theory of Democracy (New York: Harper \& Row).

Franklin, M. (2002) Learning from the Danish case: A comment on Palle Svensson's critique of the Franklin thesis, European Journal of Political Research, 41, pp. 751-757.

Franklin, M., Marsh, M. \& McLaren, L. (1994) Uncorking the bottle: popular opposition to European unification in the wake of Maastricht, Journal of Common Market Studies, 32(4), pp. 455-472.

Franklin, M., Marsh, M. \& Wlezien, C. (1994) Attitudes toward Europe and referendum votes: a response to Siune and Svensson, Electoral Studies, 13(2), pp. 117-121.

Franklin, M., van der Eijk, C. \& Marsh, M. (1995) Referendum outcomes and trust in government: public support for Europe in the wake of Maastricht, West European Politics, 18(3), pp. 101-117.

Franklin, M. \& Wlezien, C. (1997) The responsive public: issue salience, policy changes, and preferences for European unification, Journal of Theoretical Politics, 9, pp. 347-63.

Gabel, M.J. (1998a) Interest and Integration. Market Liberalization, Public Opinion and European Union (Ann Arbor, MI: The University of Michigan Press).

Gabel, M.J. (1998b) Public support for European integration: an empirical test of five theories, The Journal of Politics, 60(2), pp. 333-54.

Garry, J., Marsh, M., Kennedy, F. \& Sinnott, R. (2002) Voting behaviour in EU referendums: a Dublin case study. Unpublished manuscript, Queen's University Belfast, Trinity College Dublin and University College Dublin.

Jaccard, J. (2001) Interaction Effects in Logistic Regression (Thousand Oaks, CA: Sage).

Jacoby, W.G. (2000) Issue framing and public opinion on government spending, American Journal of Political Science, 44(4), pp. 750-767.

Kahn, K.F. \& Kenney, P.J. (1997) A model of candidate evaluations in senate elections: the impact of campaign intensity, The Journal of Politics, 59(4), pp. 1173-1205.

King, G., Tomz, M. \& Wittenberg, J. (2000) Making the most of statistical analyses: improving interpretation and presentation, American Journal of Political Science, 44(2), pp. 347-61.

Krosnick, J.A. (1988) Attitude importance and attitude change, Journal of Experimental Social Psychology, 24, pp. 240-255.

Kuklinski, J.H., Quirk, P.J., Jerit, J. \& Rich, R.F. (2001) The political environment and citizen competence, American Journal of Political Science, 45(2), pp. 410-424. 
Lavine, H., Borgida, E., Sullivan, J.L. \& Thomsen, C.J. (1996) The relationship of national and personal issue salience to attitude accessibility on foreign and domestic policy issues, Political Psychology, 17(2), pp. 293-316.

LeDuc, L. (2000) Referendums and elections: how campaigns differ. Paper presented at the European Consortium for Political Research (ECPR) Joint Sessions of Workshops, Copenhagen, 14-19 April 2000.

Lupia, A. \& McCubbins, M.D. (1998) The Democratic Dilemma: Can Citizens Learn What They Need to Know? (Cambridge: Cambridge University Press).

Nagler, J. (1994) Scobit: An Alternative Estimator to Probit and Logit, American Journal of Political Science, 38, pp. 230-255.

Nicholson, S.P. (2003) The political environment and ballot proposition awareness, American Journal of Political Science, 47(3), pp. 403-410.

Norton, E.C., Wang, H. \& Ai, C. (2004) Computing interaction effects and standard errors in logit and probit models, The Strata Journal, 4(2), pp. 103-116.

Shaw, D. \& Martin, S. (1992) The function of mass media agenda setting, Journalism Quarterly, 69, pp. 902-920.

Siune, K., Svensson, P. \& Tonsgaard, O. (1994a) Fra et nej til et ja (Aarhus: Politica).

Siune, K., Svensson, P. \& Tonsgaard, O. (1994b) The EU: The Danes said "no" in 1992, but "yes" in 1993: how and why?, Electoral Studies, 13(2), pp. 107-116.

Stoker, L. \& Bowers, J. (2002) Designing multi-level studies: sampling voters and electoral contexts, Electoral Studies, 21(2), pp. 235-267.

Svensson, P. (1994) The Danish yes to Maastricht and Edinburgh. The EC referendum of May 1993, Scandinavian Political Studies, 17(1), pp. 69-82.

Svensson, P. (2002) Five Danish referendums on the European Community and European Union: A critical assessment of the Franklin thesis, European Journal of Political Research, 41, pp. 733-750.

Tomz, M., Wittenberg, J. \& King, G. (2003) CLARIFY: Software for Interpreting and Presenting Statistical Results, Version 2.1., Stanford University, University of Wisconsin and Harvard University. Available at http://gking.harvard.edu/clarify/docs/clarify.html.

Westlye, M.C. (1991) Senate Elections and Campaign Intensity (Baltimore: Johns Hopkins University Press).

Zaller, J. (1991) Information, values and opinion, American Political Science Review, 85(4), pp. 1215-1237.

Zaller, J. (1992) The nature and origins of mass opinion (Cambridge: Cambridge University Press). 